\title{
Analisis dan perancangan penggunaan bluetooth pada kontrol lampu di smarthome sistem
}

\author{
Asih Candrakasih ${ }^{* 1}$ dan Prita Haryani ${ }^{2}$ \\ 1 Jurusan Informatika, Institut Sains \& Teknologi AKPRIND Yogyakarta \\ Jl. Kalisahak No.28 Komplek Balapan Yogyakarta \\ asihcandrakasih428@gmail.com \\ 2 Jurusan Informatika, Institut Sains \& Teknologi AKPRIND Yogyakarta \\ Jl. Kalisahak No.28 Komplek Balapan Yogyakarta \\ pritaharyani@akprind.ac.id
}

\begin{abstract}
Abstrak
Dewasa ini, perkembangan teknologi tidak hanya pada penemuan alat-alat baru yang lebih cangih, akan tetapi berpengaruh juga pada perkembangan peralatan elektronik dalam rumah yang biasa disebut dengan smarthome. Banyak sensor atau perantara yang digunakan pada smart home system dengan kekurangan dan kelebihannya masing-masing. Akan tetapi pengontrolan menggunakan bluetooth terbilang lebih mudah, tidak memerlukan biaya yang besar dan tidak memerlukan identifikasi biometrik seperti suara atau wajah yang terkadang tak terbaca. Artikel ini membahas perancangan yang dibuat menggunakan arduino uno, modul bluetooth $\mathrm{HC}-05$ dan aplikasi android untuk mengontrol lampu. Metode yang digunakan dalam penelitian ini menggunakan Systems Development Life Cycle (SDLC). Hasil dari penelitian yang telah dilakukan diketahui bahwa dengan satu arduino dan satu modul bluetooth HC-05 dapat dipakai untuk menyalakan lebih dari satu lampu atau LED. Pengontrolan lampu pada aplikasi dapat dilakukan dengan satu tombol untuk satu lampu atau satu tombol untuk semua lampu. Pada hasil analisis diketahui bahwa kinerja kedua versi bluetooth yang digunakan dalam penelitian ini yaitu v3 dan v4 dapat terpengaruh oleh WiFi jika dinyalakan secara bersamaan. Kedua versi bluetooth yaitu v3 dan v4 dapat tersambung sampai jarak 20 meter di luar ruangan dan 10 meter di dalam ruangan.
\end{abstract}

Kata Kunci arduino uno, smarthome, jarak bluetooth, pengaruh WiFi, android

\section{Pendahuluan}

Smarthome adalah salah satu dari sistem pengendali rumah yang memberikan kenyamanan kepada pemilik rumah untuk mengendalikan peralatan elektronik menggunakan android. Dengan perkembangan teknologi, android dapat digunakan sebagai home controller, salah satunya mengontrol lampu dari jarak jauh. Sistem saklar pada lampu dapat digantikan dengan menggunakan perangkat relay dan dikendalikan melalui sebuah perangkat mikrokontroler berbasis jaringan sehingga dapat terhubung ke smartphone yang telah terinstall program pengendali smarthome [1].

Mengontrol lampu dari jarak jauh menggunakan arduino dapat dilakukan menggunakan beberapa metode diantaranya menggunakan sensor suara, gerak, suhu, dan cahaya. Selain menggunakan sensor, pengontrolan lampu menggunakan arduino juga dapat dilakukan melalui perantara diantaranya adalah internet dan bluetooth. Beberapa penelitian yang sudah pernah dilakukan terhadap kontrol lampu menggunakan sensor suara ditemukan

* Corresponding author.

(c) () Asih Candrakasih dan Prita Haryani;

licensed under Creative Commons License CC-B 
kekurangan yaitu akurasi belum mencapai $100 \%$ dan pada pengguna yang dapat mengakses lampu hanya orang yang sudah memasukkan sampel suara [2].

Pada penelitian lain menggunakan sensor suara KY-038 ditemukan kekurangan yaitu hanya dapat mendeteksi 17 dari 30 data dan pada sensor suhu MLX90614 belum cukup akurat dalam pendeteksiannya [3]. Penelitian lain pada kontol lampu melalui internet [4], tidak begitu cocok jika dilakukan pada smarthome yang masih memiliki keterbatasan jaringan Internet, dimana faktor koneksi dan kecepatan akses menjadi kendala yang dapat terjadi. Pengontrolan lampu menggunakan internet akan cocok diterapkan pada fasilitas umum, kantor atau lokasi yang telah memiliki fasilitas koneksi Internet yang baik.

Pada beberapa penelitian yang pernah dilakukan oleh [1] menjelaskan bahwa penggunaan arduino, bluetooth, dan pemanfaatan android dapat mempermudah pengendalian alat elektronik seperti lampu. Penelitian lain yang dilakukan oleh [5] menjelaskan bahwa fungsional masukan pengguna dan pembacaan kondisi lampu oleh bluetooth sudah memperoleh hasil yang bagus. Pada penelitian yang dilakukan oleh [6] menjelaskan bahwa jarak jangkauan bluetooth yang dapat digunakan untuk pengontrolan lampu mencapai 20 meter pada ruang tertutup dan 62 meter dari ruangan terbuka atau dari luar rumah. Diketahui dari ketiga penelitian tersebut bahwa penggunaan bluetooth dapat mempermudah pengendalian alat elektronik juga tidak memerlukan bantuan jaringan Internet dan sampel biometrik seperti suara untuk mengontrol lampu.

\section{Metodologi}

Metode yang digunakan dalam penelitian ini adalah Systems Development Life Cycle (SDLC). Menurut [7], metode SDLC dapat digunakan untuk proses pengembangan framework dan dalam pengembangan framework dibutuhkan beberapa tahapan yang ada pada SDLC yaitu planning, analysis, design, implementation, dan maintenance. Diagram alir kerja dari program yang digunakan dalam penelitian ini adalah tertampil dalam Gambar 1.

Sebelum aplikasi dijalankan, bluetooth terlebih dahulu harus dihidupkan dan dilakukan pairing antara bluetooth android dan modul bluetooth HC-05 yang sudah terpasang dalam arduino. Aplikasi dalam smartphone diwakili dengan ikon berwana kuning dan putih untuk menyalakan dan mematikan lampu. Penekanan ikon lampu berwarna kuning akan menyimpan dengan data ' 1 ' untuk lampu yang tersambung pada pin 2 kemudian akan memberi perintah output 'HIGH' untuk menyalakan lampu. Kemudian untuk mematikan lampu, tekan ikon lampu berwarna putih'yang akan tersimpan dengan data 'A' untuk lampu yang tersambung pada pin 2 kemudian akan memberi output 'LOW' untuk mematikan lampu. Hal yang sama juga berlaku untuk lampu yang tersambung pada pin 3 dan tersimpan dengan data '2' untuk menyalakan lampu dan data 'B' untuk mematikan lampu dan seterusnya.

Pengujian sistem dilakukan dengan dua percobaan yakni dilakukan di dalam ruangan bersekat dan di luar ruangan. Jarak antara smartphone dan alat kontrol lampu diuji per 10 meter dalam pengujian. Pengujian juga diakukan untuk melihat apakah adanya koneksi sinyal WiFi yang digunakan dalam smartphone mempengaruhi koneksi dengan alat kontrol lampu. Perbedaan versi bluetooth yang digunakan dalam smartphone yakni versi v3 dan v4 dilihat dalam penelitian ini. Berapa lama waktu yang dibutuhkan untuk menyalakan lampu dari smartphone juga dihitung dalam penelitian ini. Arsitektur sistem yang digunakan dalam penelitian ini seperti tertampil dalam Gambar 2.

Langkah pertama pengujian dilakukan adalah menentukan tempat percobaan yaitu apakah akan di luar atau di dalam ruangan yang bersekat, kemudian mengambil jarak per10 meter antara bluetooth pada smartphome android dan bluetooth HC-05 yang tersambung 


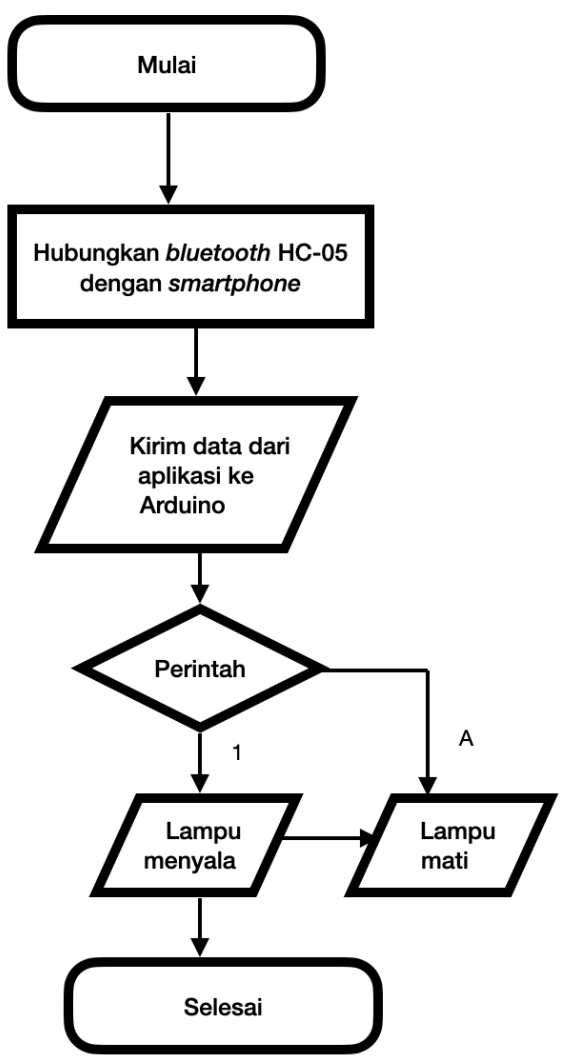

Gambar 1 Diagram alir cara kerja program

dengan arduino.

Langkah kedua selanjutnya adalah menentukan apakah akan menguji performa jika tersambung WiFi terlebih dahulu atau saat WiFi dalam keadaan mati. Berapa lama waktu yang dibutuhkan untuk menyalakan lampu setelah tombol ditekan merupakan nilai yang dihitung dalam penelitian ini.

\section{Hasil dan pembahasan}

Kondisi penelitian yang dilakukan untuk melihat kinerja blueooth $\mathrm{v} 3$ dan bluetooth $\mathrm{v} 4$ ada 4 jenis, yaitu di dalam ruangan yang bersekat atau di luar ruangan dan terhubung WiFi atau tidak Terhubung WiFi. Dari hasil analisis yang sudah dilakukan, dapat dilihat perbedaannya dari rata-rata selisih waktu lampu menyala di luar ruangan dengan jarak 10 dan 20 meter adalah seperti tertampil dalam Tabel 1.

Dari rata-rata selisih waktu lampu menyala dijarak 10 meter di luar ruangan dapat dilihat bahwa bluetooth $\mathrm{v} 4$ lebih unggul dari kedua percobaan baik tanpa WiFi maupun saat menggunakan WiFi. Jika masing-masing versi bluetooth dibandingkan berdasarkan kondisi percobaan, maka diketahui bahwa data lebih cepat diterima saat kondisi tanpa menggunakan WiFi atau saat WiFi dimatikan.

Pada percobaan yang dilakukan di luar ruangan dengan jarak 20 meter ditemukan permasalahan terkadang dengan bluetooth $\mathrm{v} 3$ tidak dapat terhubung dan perlu dilakukan 


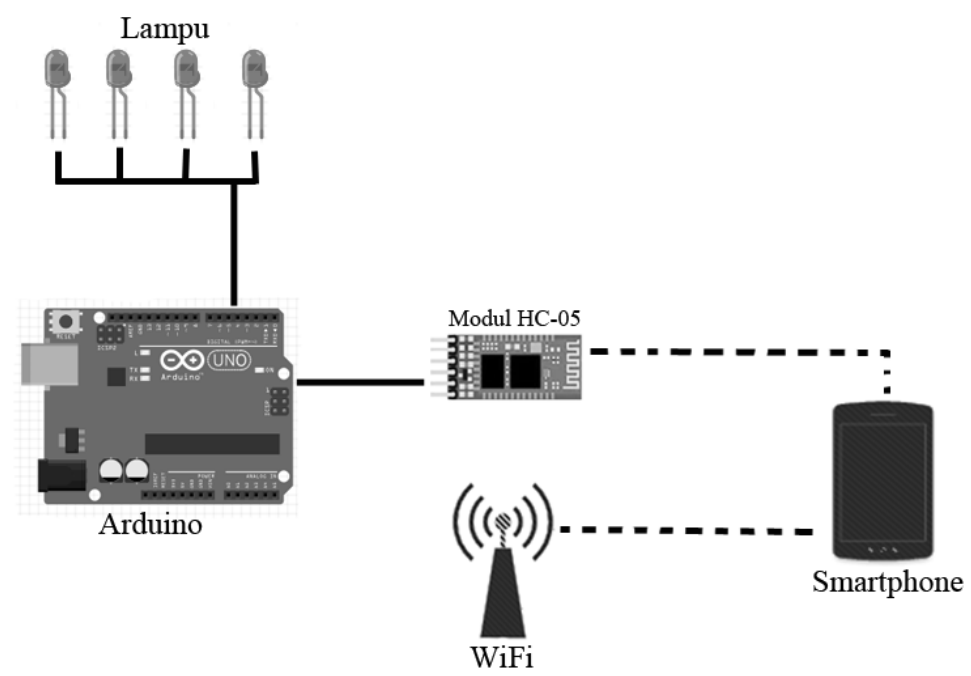

Gambar 2 Arsitektur sistem

Tabel 1 Hasil koneksi di luar ruangan jarak $10 \mathrm{~m}$ dan $20 \mathrm{~m}$

\begin{tabular}{l|l|l|l}
\hline versi bluetooth & WiFi & $\begin{array}{c}\text { jarak } 10 \mathrm{~m} \\
\text { waktu(detik) }\end{array}$ & $\begin{array}{c}\text { jarak } 20 \mathrm{~m} \\
\text { waktu(detik) }\end{array}$ \\
\hline v3 & tidak terhubung & 0.7 & 0.622 \\
& terhubung & 0.807 & 1.078 \\
v4 & tidak terhubung & 0.589 & 0.434 \\
& terhubung & 0.682 & 0.598 \\
\hline
\end{tabular}

percobaan sekitar 4 kali untuk menyambungkan bluetooth kembali. Nampak bahwa bluetooth versi v4 memiliki keunggulan dibanding dengan v3 baik dan tidak dipengaruhi oleh koneksi sinyal WiFi. Perbandingan pengujian jarak berhenti di 20 m karena bluetooth v3 sudah tidak mampu dengan baik merespon dalam jarak tersebut.

Pengujian di dalam ruangan yang memiliki sekat, secara umum memberikan hasil yang serupa dimana bluetooth versi v4 memiliki respon lebih baik dari versi sebelumnya. Tabel 2 merupakan hasil pengujian dalam ruangan dengan sekat.

Tabel 2 Hasil koneksi di dalam ruangan bersekat jarak $10 \mathrm{~m}$

\begin{tabular}{l|l|l}
\hline versi bluetooth & WiFi & $\begin{array}{c}\text { jarak } 10 \mathrm{~m} \\
\text { waktu(detik) }\end{array}$ \\
\hline v3 & tidak terhubung & 0.745 \\
& terhubung & 0.862 \\
v4 & tidak terhubung & 0.574 \\
& terhubung & 0.585 \\
\hline
\end{tabular}

Pengujian dalam ruangan bersekat ini, bluetooth sudah tidak mampu terkoneksi saat diujicoba pada jarak $20 \mathrm{~m}$. Target awal analisis adalah 60 meter setelah melihat penelitian yang dilakukan oleh [6] dimana jarak maksimal bluetooth disebut dapat mencapai 62 meter di luar ruangan tidak dapat dilaksanakan. Perbedaan alat baik smartphone maupun modul arduino perlu diteliti lebih lanjut untuk bisa menghasilkan jarak yang lebih jauh. 


\section{Kesimpulan dan saran}

Dari hasil penelitian nampak bahwa kinerja bluetooth dipengaruhi oleh jarak, pembatas atau sekat yang terdapat dalam ruangan, versi bluetooth dan sinyal WiFi yang dinyalakan pada smartphone. Maksimal jarak yang dapat dijangkau oleh bluetooth v3 dan v4 di dalam ruangan bersekat adalah 10 meter. Sedangkan maksimal jarak yang dapat dijangkau oleh kedua versi bluetooth di luar ruangan adalah 20 meter, akan tetapi pada bluetooth v3 agak sulit untuk dapat terhubung dengan baik.

Pengujian dengan melihat detail dari modul bluetooth seperti HC -05 dan detail dari bluetooth yang digunakan dalam smartphone perlu dilakukan agar mampu memberikan gambaran hasil yang lebih baik. Penanganan error pada aplikasi yang mampu mendeteksi jika terjadi kesalahan pada bluetooth sehingga tidak terjadi koneksi perlu dilakukan.

\section{Pustaka}

1 M. Muslihudin, W. Renvillia, T. Taufiq, A. Andoyo, and F. Susanto, "Implementasi aplikasi rumah pintar berbasis android dengan arduino microcontroller," Jurnal Keteknikan dan Sains (JUTEKS), vol. 1, no. 1, pp. 23-31, 2018.

2 A. Faroqi, M. S. WS, and R. Nugraha, "Perancangan sistem kontrol otomatis lampu menggunakan metode pengenalan suara berbasis arduino," TELKA-Telekomunikasi, Elektronika, Komputasi dan Kontrol, vol. 2, no. 2, pp. 106-117, 2016.

3 M. P. Lukman, Y. F. Y. Rieuwpassa et al., "Sistem lampu otomatis dengan sensor gerak, sensor suhu dan sensor suara berbasis mikrokontroler," Jurnal RESISTOR (Rekayasa Sistem Komputer), vol. 1, no. 2, pp. 100-108, 2018.

4 E. A. Satya, Y. Christiyono, and M. Somantri, "Pengontrolan lampu melalui internet menggunakan mikrokontroller arduino berbasis android," Transient: Jurnal Ilmiah Teknik Elektro, vol. 5, no. 3, pp. 358-367, 2017.

5 A. D. B. Sadewo, E. R. Widasari, and A. Muttaqin, "Perancangan pengendali rumah menggunakan smartphone android dengan konektivitas bluetooth," Jurnal Pengembangan Teknologi Informasi dan Ilmu Komputer e-ISSN, vol. 2548, p. 964X, 2017.

6 A. Mulyanto, Y. A. Nurhuda, and I. Khoirurosid, "Sistem kendali lampu rumah menggunakan smartphone android," Jurnal Teknoinfo, vol. 11, no. 2, pp. 48-53, 2017.

7 L. O. M. Saidi, "Pengembangan framework untuk investigasi email forensics menggunakan metode systems development life cycle (sdlc)," Master's thesis, 2017. 